potential usefulness of BIOSIS as an adjunct to literature searching in the behavioral sciences. Although some respondents indicated they used BIOSIS for studies involving animal experiments, recent literature does suggest its usefulness to a wide range of applications in the field of psychology. However, the relatively higher cost of accessing BIOSIS in relation to other useful files, such as Medline or ERIC, may mitigate against its use.

The relatively low use of BIOSIS for psychology research may also be a reflection of the lack of marketing and availability of basic information on its potential usefulness to behavioral science librarians. Specialized workshops, professional publications, and commentary in BioSearch could be an effective method of promoting its value to researchers pursuing topics in psychology. BIOSIS would thus attain a higher visibility among endusers.

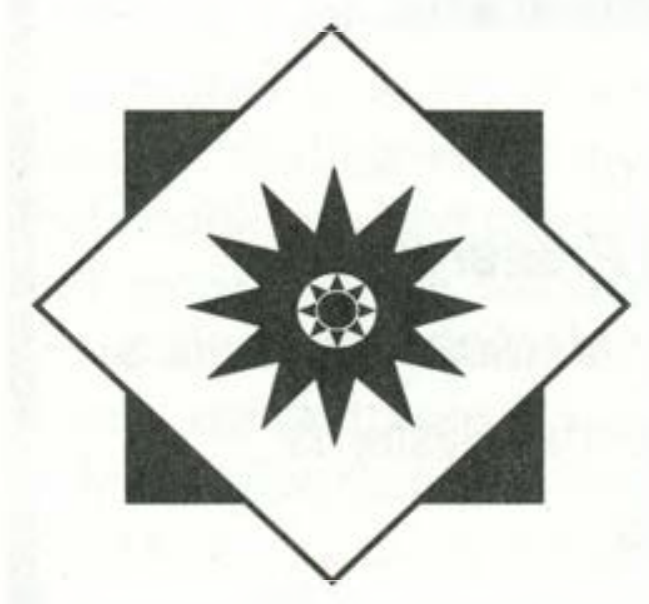

\title{
INNOVATIONS
}

\section{Humor and creativity: Library committees}

\author{
By Norman D. Stevens
}

Director

The Molesworth Institute

In my initial introduction to what has turned out to be a longer than anticipated series of short pieces on contemporary library humor and, to a lesser degree, creativity, I commented on some of the virtues of humor in the library workplace. One of those virtues, I suggested, was the extent to which the development of an inbred sense of humor among the members of the committees that so dominate the life of most academic libraries helped alleviate the tedium of committee work. Indeed one of my few and fondest recollections of serving as chair of the University of Connecticut Libraries' MRAP (Management Review and Analysis Program) Committee foisted off on us by ARL's newly established Office of Management Studies in the early 1970s is of the light-hearted approach to our work that safely carried us through to a successful conclusion. I am sure that I still have buried in my files somewhere the extensive list of alternative adjectives to express varying degrees of confidence in our conclusions that we developed as a handybut never applied — guide to the editing of our final report. Much, if not all, of that internal committee humor is so inbred that it makes little sense to outsiders even in the same library. Nor is most of it published or distributed very widely so it is among the scarcest kinds of library humor.

Not to worry. Committees have become so prevalent as a way of life in academic libraries and library associations and organizations that there is no lack of independent outside humor addressing the serious impact that committees have on our inability to get our real work done. Unfortunately few of us have either the power or the wisdom demonstrated by one of our best-known and bestbeloved college librarians who has firmly told his staff that he is available to attend committee meetings only before lunch. The widespread adoption of WAM's Law of Creativity-I hesitate to give him the full credit he is due for fear it will lead to censure by the ACRL Committee on Committees-would do more to increase productivity in academic libraries than any other step we might take. 


\section{EDUCATION FOR LEADERSHIP IN THE 21ST CENTURY}

School of

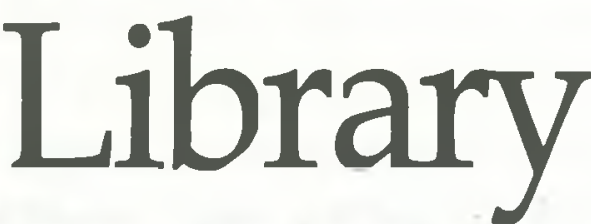

Service

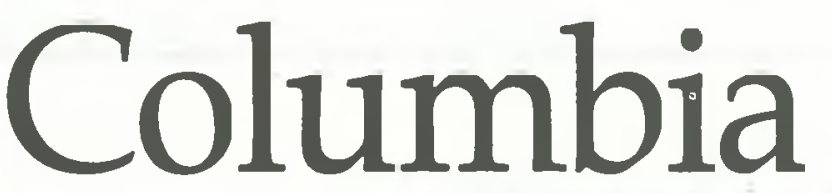

University

\section{announces}

an exciting expanded MS program that will emphasize specializations in:
- Academic and Research Librarianship

- Archives Management and Organization

- Bibliographic Control

- Conservation and Preservation

- Health Science and Medical Informatics

- Information Science and Systems

- Information Services

- Law Librarianship

- Management and Administration

- Public Librarianship

- Rare Books, Special Collections, and Bibliography

- Special Libraries, Information Centers, Independent Specialties/Consultancies

In this dynamic new program priority will be given to methods, principles, and specializations, forty-eight credit hours required. Special internships available.

Qualified students may finance studies with scholarship and fellowship grants from the University and other sources, with educational loans, and with part-time or full-time work/study arrangements.

A free video is available upon request.

For information about the Master's, Certificate, or Doctoral programs:

School of Library Service 516 Butler Library

Columbia University New York, New York 10027 212-854-2292

An Equal Opportunity Educator/Employer 


\section{The true nature of committees}

A careful review of the Molesworth Institute's Archives of Library Humor has, as you might expect, turned up a wide variety of comments, few of them favorable but almost all of them revealing, on the true nature and the insidious role of the dreaded library committee. There are, as we will see, some serious lessons to be drawn from these observations as well as a general conclusion. The general, and obvious, conclusion is that although the committee, even when disguised as a task force or "working" group, may have become the most common means of attempting to use a body of library staff to arrive at a series of recommendations for dealing with a major problem, the claim that people working together can arrive at sounder and more creative solutions than those working alone is not widely believed. Staff attitudes towards library committees, as well as administrative insight, suggest that academic library administrators need to be far more circumspect and judicious in their use of that approach to problem solving. Here endeth the sermon.

\section{The record}

Actually the record, as revealed in various library newsletters and other ephemera, clearly indicates that their common dislike for committees may be one of the few areas in which there is agreement between academic library administrators and staff. We all have a cynical attitude towards the use and value of committees even as we continue to appoint and serve on them. If we either dislike committees, or regard them-at best-as a necessary evil, why do we continue to have so many of them? perhaps there is a major character flaw among librarians that warrants mass psychoanalysis.

So far I have turned up no ode to the library committee or little evidence that music librarians, despite their otherwise peculiar nature, make much use of committees, but otherwise the record is replete with delightful examples. In the Law Librarians of New England News (December 1988) Mary Jane Kelsey and Jo-Anne Giammattei, of the Yale University Law Library, proposed a Law of Library Inverses: "Meeting length and committee size is inversely proportional to the importance of the agenda." A somewhat similar view was expressed in the 1987 April Fool's issue of Mullings from the University of Arkansas Library where a contest to revise forms within the library was announced. The fifth rule of the contest provided that "No more than one committee, composed of no more than three persons, may meet no more than one hour to determine the form of the revision." The Biblio-Fobe (April 1, 1989) from the San Diego State University Library, contained a listing pre- pared by Harry (I Love Committee Work) Keehan of several potential OPAC committees that didn't, alas, make it past the final cut. Those included: the Terminal Courtesy and Color Scheme Committee; the Card Catalog Demolition Tag Teams Committee; and the Remote Access from Outer Planets Committee. A limited edition computer-generated advice column from the Health Sciences Library at the Oregon Health Sciences University contains, among other gems, a response from the regular columnist, Miss Braithwaith, to Sue Snow, who has lamented the lack of excitement in her life. Miss Braithwaith asks: "Have you considered committee work? After a hard week of struggling with the application of the AACR rules, I find the meeting of

\section{Feeling funny?}

Fortunately or unfortunately, depending on your point of view, my last column on library poetry did not, contrary to the dire predictions of editors and friends, inundate me with what passes for library poetry written by frustrated, would-be poets who have had to settle for a career in librarianship to support their habit. The most common response to my efforts to date, as is evident from the few letters to the editor that have been published, have been the cries of outrage from science librarians, and especially chemistry librarians, who took offense at my passing comment on the demonstrated lack of a sense of humor not only among them but among the scientists they serve at work or at home.

As I have pointed out to them, as an associate editor for information sciences for the Journal of Irreproducible Results, which is the premier international vehicle for science humor, I am fully aware of the sense of humor that does exist among scientists. I am still puzzled, if not distressed, by the dearth of science library humor. The few examples cited are not an adequate sample and I am still awaiting scientific proof, which is what science is all about after all, that there is such a thing as science library humoras opposed to library science humor or even science library science humor. Further examples are welcome. When I have enough to write a column on the subject, I'll publicly apologize and concede the error of my ways. As always send that, and any other intentional or unintentional examples of library humor, to me at 143 Hanks Hill Road, Storrs, CT 06268. Don't forget the business cards (signed and dated on the verso), library postcards, and other fine examples of library ephemera. Thanks.Norman D. Stevens. 
a committee to be stimulating to the verge of exultation.... I am sure you will find, as I have, that committee work (while it does take some time away from other creative pursuits) is exactly the stone to keep a keen edge on one's intellectual razor."

As might be expected, Mike Valinis of the Ohio State University Libraries has frequently used his sharp wit to reveal in News Nosey the true nature of committee work there. The Turkey Week 1988 issue, for example, announced the formation of a Search Committee Department to "relieve the faculties and staff of present duties and free up time for all the other committees and task forces on which they should be serving." His best effort, however, came in the April 1, 1984, issue where, under the apt heading, "Another New Committee," he revealed that: "The Liberry administration has announced the formation of a new committee, the Rubber Stamp Committee, which will meet on a regular basis to give formal approval to any of the administration's decisions, thus foregoing the need for contentious and time-consuming task forces. Members have yet to be announced." Just as staff are wary of committees, though, so are administrators. In his advice to an associate leaving to become a library director elsewhere, Jay Lucker, in the July 1989 issue of the MIT Libraries Notes, spoke to the matter. He cautioned her to "avoid the temptation to appoint committees. They have a life of their own and will come and go without any intervention on your part."

Despite our cynical attitude and our gentle, or not so gentle, carping, committees remain at the heart of the academic library's accepted mode of operation. We couldn't do without them so we are fortunate that they can inadvertently give us so much pleasure as prime targets for our humor.

\section{Sailing the seas of information at Cleveland State}

\section{By Billie Reinhart}

\author{
Coordinator of Bibliographic Instruction \\ Cleveland State University
}

\section{and Gary Thompson}

\author{
Hecid of Information Services \\ Cleveland State University
}

Library orientation followed a little different approach this year at Cleveland State University. In July, the dean of student life met with the director of the library, the head of information services, and the coordinator of bibliographic instruction, to explain that the Student Life Department had designed a new format for the university orientation of incoming students this year, with less emphasis on the traditional informational talks and more emphasis upon student participation. Students were divided into teams and given points for events throughout the day. The orientation had a nautical theme after the school team, the Vikings. Two separate orientations took place, first in late August for over two hundred students, and the second in mid-September for over four hundred.

For its part of the orientation, the library designed an event that would be both fun and a learning experience. In previous years librarians had given fifteen-minute talks about the library collection and services to groups of twenty-five to thirty students in classrooms away from the library. This year the students were brought to the library on two separate days for forty-five minute orientation periods. The Bibliographic Instruction Team decided that the orientation would combine the nautical theme with the new trend toward information literacy, and thus came up with the theme, "Sailing the Seas of Information at the CSU Library." Instead of lectures, the team integrated two different approaches to library instructionnamely, the self-guided tour and the use of cue cards. The latter idea was publicized recently in the library literature. ${ }^{1}$ Students moved around the library to visit different "ports," each of which had a large cue card to explain the function of that area of the library, the reference center, the new book section, the author/title catalog, the subject catalog, the general periodical indexes (Infotrac and Readers' Guide), and the reserve and circulation desks. Incidentally, two weeks after the orientation, the card catalog was replaced by Scholar, the new online public access catalog based on the NOTIS System.

The logistics for moving one hundred to two hundred students smoothly through nine ports in forty-five minutes took lots of imagination and creativity. The BI team designed a "Passport to

'Bethany Lawton and Ann Pederson, "Cue Card Clues: A New Approach to Library Orientation," Research Strategies 6 (Spring 1988): 77-79. 